\title{
Communication Strategy Planning Of Majelis Taklim In Implementation Recitation Program
}

\author{
Idawati \\ idawatiuir@comm.uir.ac.id \\ Benni Handayani \\ bennihandayani@comm.uir.ac,id \\ Fakultas Ilmu Komunikasi Universitas Islam Riau
}

\begin{abstract}
Majelis Taklim is a Non-Formal Islamic Education Society, as a forum for connecting silaturrahim, intensify ukhuwah Islamiyah, increasing faith and devotion to Allah subhanahu wa ta'ala , and popularize Islamic Da'wah. The purpose of this study is to find out how the Majelis Taklim's efforts in improving recitation. This study uses a descriptive qualitative method in which the writer describes the efforts of the Majelis Taklim in increasing recitation through interview techniques to woman as a member of Majelis Taklim with a population of 40 person. The sampling technique that using is total sampling techniques.
\end{abstract}

Keywords: Recitation; Majelis Taklim; Dakwah Islamiyah; Social Institution

\section{INTRODUCTION}

Majelis Taklim is an association of Muslim women who are active in the recitation and Islamic da'wah. This women association is a routine activity in filling the spirit of Islamic recitation, such as religious study activities by the Ustadz and Ustadzah which discusses the study of Islamic jurisprudence, creed, morals, recitation of the Surah Yasin together, program of Khatam Al-Qur'an, and then filling activities on special days such as the Prophet Muhammad's birthday, and Isra 'mi'raj. To increase recitation activities so that they remain much in demand by members and stick to Islamic concepts and love of reading the Qur'an, these women must be able to instill awareness in themselves to keep working together to formulate work programs that are considered a mainstay and breakthrough program that new, which is based on, strengthen ukhuwah Islamiyah, love reading the Qur'an, and increase faith and devotion to Allah Subhanahu Wata'ala and Prophet Muhammad Salallahu Alaihi Wassalam.

In mobilizing a program in an institution, it is very necessary planning and communication strategies because, without planning and communication strategies, the program of activities will not be able to run properly as well as in society institutions such as majelis taklim, urgently needed these efforts are intended to get a positive response from the community. Based on pre-research interviews conducted with the chairman of Majelis Taklim Permata Sukajadi, a few days back, the recitation activity in Majelis Taklim Permata has decreased from before, this is caused by several factors:

1. The community still has low awareness to participate in the recitation

2. The program is still not running optimally

3. Lack of planning and strategies were undertaken in carrying out activities 
Can be seen from several factors causing the decline in study activities will be overcome by arranging and compiling planning and communication strategies in carrying out the Majelis Taklim activities.

\section{Theoretical Framework}

Planning is a process to determine where we need to go by identifying what conditions must be met to get there most efficiently and effectively. planning also means setting the specifications of the goals to be achieved including the ways that will be used to achieve these objectives. (Keufman, 1972).

The planning function is:

1. Identify and define the problem

2. Give direction or goals to be achieved, especially in overcoming uncertainty by choosing the best path. Even in stable conditions planning is still needed.

3. Minimize the occurrence of waste of resources in order to achieve goals effectively

4. Make estimates (forecasting) of the obstacles that might occur and the results (output) that will be obtained.

5. Controlling the implementation so that it always remains in the corridor of the planning that has been set.

\section{Strategic Communication Planning}

The term communication planning refers to the communication policy that sets alternatives for achieving communication objectives that set alternatives for achieving long-term goals, as well as being the basic framework for short-term operational planning, strategic planning is realized in targets that can be quantified by systematic approaches to the objectives wants to be achieved according to communication policies (Hancock, 1981).

\section{Basic of Strategic Planning}

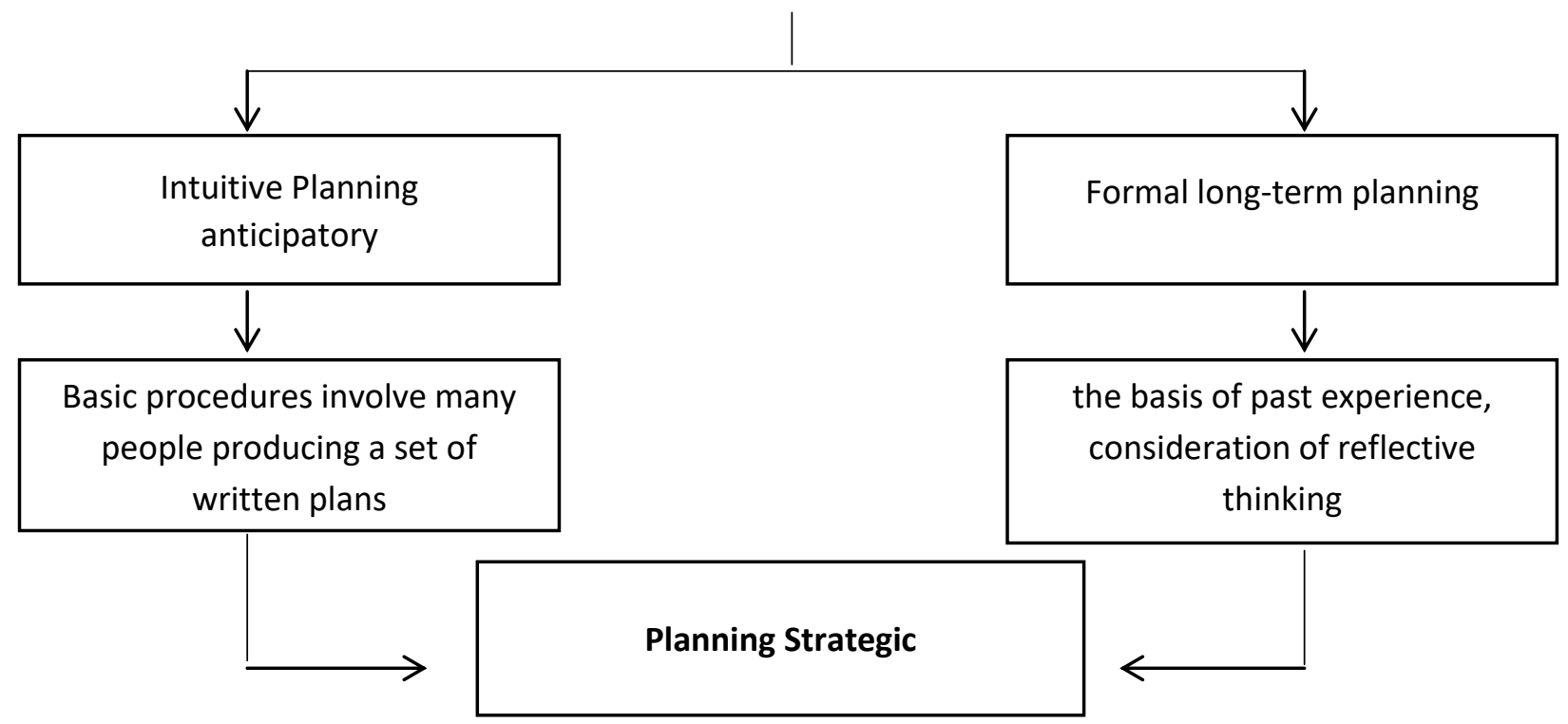

FIGURE 1: Basic Strategic Planning 


\section{Social Institution}

The government through Undang-Undang No. 32 tahun 2004 regarding regional government has opened opportunities for the community to form a social institution, as a place for the community to help each other and help each other to fulfill their daily needs, in general, society institutions consist of formal and informal institutions, formal community institutions are institutions that are funded and sponsored by the government. According to Sokeanto (2003): "The role is a dynamic aspect of the position (status). If a person carries out his rights and obligations according to his position then he carries out a role. The distinction between position and role is in the interest of science. Both are inseparable because they depend on each other. There is no role without a position and vice versa. The purpose of forming a social institution is to maintain and preserve the values of community life based on the values of mutual cooperation and family because mutual cooperation and family are the main joints in social life in Indonesia.

If viewed in terms of the objectives of the Majelis Taklim including Islamic preaching institutions or facilities that are self-standing and self-disclosed can regulate and carry out their activities, in which developing democratic principles based on deliberation to reach consensus for the smooth implementation of Majelis Taklim in accordance with a work program that has been prepared with its member, as written in the Qur'an surrah AlMujadalah verses number 11:

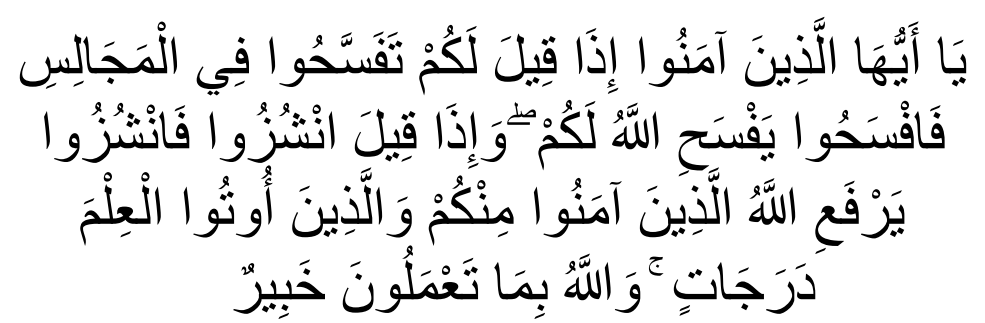

O you who have believed, when you are told, "Space yourselves" in assemblies, then make space; Allah will make space for you. And when you are told, "Arise," then arise; Allah will raise those who have believed among you and those who were given knowledge, by degrees. And Allah is Acquainted with what you do. (Surah Al-mujadalah 11)

So the purpose of the Majelis Taklim Activity is: "to form Muslim women who always want to increase their Islamic knowledge, strengthen their faith and belief in Allah, by our guidelines namely the Qur'an. Allah says in surah Al-an'am verse 155:

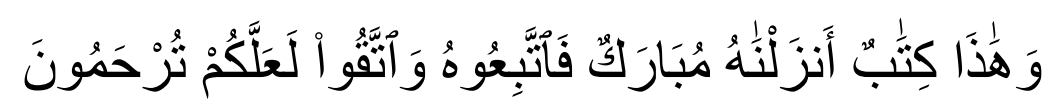

And the Qur'an is a book We revealed (which is) blessed, so follow it and fear Allah that you may receive mercy. (Surah Al-an'am 155)

\section{METHOD}

In this study, researchers used qualitative research methods because the form of this study allows researchers to be able to describe the object of research holistically based on social reality in the field. According to Bodgan and Taylor (in Moleong, 2007: 3) "Qualitative 
methods as a research procedure that produces descriptive data in the form of written or oral words from people and observable behavior". This research is a descriptive study, with more of a description of the results of interviews and documentation studies. The data that has been obtained will be analyzed qualitatively and described in a descriptive form.

This research is a descriptive study, with more of a description of the results of interviews and documentation studies. The data that has been obtained will be analyzed qualitatively and described in a descriptive form.

\section{DISCUSSION}

\section{Communication strategy planning in running the Majelis Taklim program}

Planning is essentially an effort that is done consciously and continuously and managed to choose good alternatives to achieve certain goals. In this case, of course, efforts are carried out continuously by the management and members of Majelis Taklim Permata Sukajadi in carrying out routine programs.

Following are the results of the researchers' interview with the head of Majelis Taklim Permata Sukajadi about, How is the Majelis Taklim communication strategy planning in carrying out routine programs?

"Basically, as the chairman and board of the Majelis Taklim Permata Sukajadi management, they have tried their best to run routine programs in accordance with the Majelis Taklim program universally in the District, City and even Province. However, programs planned at the time they will be realized often lack positive responses from members, the causes are limited human resources, facilities, and infrastructure, limited time, lack of sense of responsibility and awareness".

Based on the results of the above interview, as Chairperson, he has tried his best to carry out routine programs that refer to the District, City and even Provincial programs but still failed to realize this, especially in terms of practicing it due to the lack of response from some members.

The researchers' interview results about, What are the internal and external inhibiting factors?

"Some internal inhibiting factors as stated above are;1. Limited human resources 2. Limitations of supporting infrastructure 3. Members' time limitations are caused by being busy 4. Lack of awareness and sense of responsibility in participating in activities. Then the external factors are: Lack of response from the government to the routine Majelis Taklim program so that this becomes an inhibiting factor that causes the emergence of obstacles from internal members of Majelis Taklim"

Some inhibiting factors consist of two factors, namely internal and external factors, internal factors are also caused by external factors that did not get a response from the local government in running the Majelis Taklim program.

The interview results of researchers about, What are the future expectations of Majelis Taklim Permata Sukajadi strategy planning in carrying out routine programs?

"In the future as a team in the management of Majelis Taklim Permata Sukajadi will make improvements to plans and strategies that are better in maintaining and improving routine programs, and trying to make specific strategies so that all 
inhibiting factors can be resolved, and internal factors as administrators have become part of our task to solve them, however if external factors are expected to be the cooperation of the whole community and regional stakeholders who will communicate them"

\section{Inhibiting factors in planning Majelis Taklim communication strategies in carrying out routine programs.}

As for overcoming the inhibiting factors in the planning and communication strategy of Majelis Taklim in carrying out routine programs, the management along with members and the entire community as well as local stakeholders and the government must work together to carry out the planning function consisting of:

1. Identifying and defining problems

2. Give direction or goals to be achieved, especially in overcoming uncertainty by choosing the best path. Even in stable conditions planning is still needed.

3. Minimizing the occurrence of wasteful resources to achieve goals effectively

4. Forecasting of the obstacles that might occur and the results (output) that will be obtained.

5. Carry out controls so that implementation always remains within the predetermined planning corridor.

And carry out strategic planning for management and members including:

1. Decisions related to the future situation of the Majelis Taklim

2. The management activities of the Majelis Taklim institutions peaked continuously

3. The results of the technical based thought process adopted by the Majelis Taklim institutions

4. Always think positive and inspiring

5. Pay attention to the set of causal consequences all the time

6. Systematically identifying opportunities and threats that will occur in the future

7. Paying attention to a series of alternative actions that are open in the future

8. Reconcile with the goals of the institution and also the objectives of the community

9. Be a guide in acting

10. Is a process of determining the vision-mission, goals, objectives, and strategies for achieving Majelis Taklim institutions (Canggara, 2013).

\section{CONCLUSION}

Based on the results of the study, it can be concluded as follows:

1. That in planning the MTPS communication strategy in carrying out routine programs, it must always cooperate with all members, the community, local stakeholders, and the government in preparing the Program, and be able to continuously promote the programs that have been prepared, strive to optimize the program for applied.

2. In overcoming obstacles in the planning of communication strategies for routine programs, the executive board and all active members, the community, regional stakeholders and the government must be able to carry out the planning and strategic planning functions. 


\section{ABOUT THE AUTHORS}

Idawati is a lecturer at the school of communication science, Faculty of Communication Sciences, Universitas Islam Riau, Indonesia.

Benni Handayani is a senior lecturer at the school of communication science, Faculty of Communication Sciences, Universitas Islam Riau, Indonesia.

\section{REFERENCE}

A. Alvin. (2006). Komunikasi Kelompok-Proses-proses Diskusi dan Penerapannya. Jakarta: UI Press.

Bungin, B. (2007). Teori, paradigma, dan Diskursus Teknologi Komunikasi di Masyarakat (Sosiologi Komunikasi). Jakarta: Kencana.

Canggara, H. (2013). Perencanaan Dan Strategi Komunikasi. Jakarta: PT Raja Grafindo Persada.

Digilib Jurnal ac. Id, Edisi 2015

Hancock, A. (1994). Communication policies, planning, and research in UNESCO: From the seventies to the nineties. Mass communication research: On problems and policies. The art of asking the right questions: In honor of James D. Halloran, 21-38.

https//www. Referensimakalah,com

Hubeis, M. (2012). Komunikasi Profesional-Perangkat Pengembangan Diri. Bogor: IPB Press.

Kaufman, R. A. (1972). Educational system planning. Englewood Cliffs, NJ: Prentice-Hall.

Moleong, lexy. (2007). Metodologi Penelitian Kualitatif. Jakarta : PT Remaja Rosdakarya Offset.

Nasution. (2003). Metode Research, Jakarta : PT. Bumi Aksara.

Rauf, R., \& Munaf, Y. (2015). Lembaga kemasyarakatan di Indonesia. Zanafa Publishing.

Soekanto, S. (2003). Judul: Sosiologi Suatu Pengantar. Jakarta: PT Raja Grafindo Persada.

Sugiyono. (2012). Memahami Penelitian Kualitatif. Bandung : Alfabeta.

Sutopo, H.B. (2002). Metodologi Penelitian Kualitatif Dasar Teori dan Terapannya Dalam Penelitian. Surakarta : Universitas Sebelas Maret.

Wayne, P. R., \& Faules, D. F. (2006). Komunikasi Organisasi. Terjemahan. Bandung: Rosdakarya. 